\title{
Reductive dissolution of arsenical ferrihydrite by bacteria
}

\author{
Erika Revesz $^{\mathrm{a}}$, Danielle Fortin ${ }^{\mathrm{a}^{*}}$, Dogan Paktunc ${ }^{\mathrm{a}, \mathrm{b}^{*}}$
}

a University of Ottawa, Department of Earth Sciences, 25 Templeton St., Ottawa, Ontario, Canada, K1A 3N5.

${ }^{\mathrm{b}}$ CANMET Mining and Mineral Sciences Laboratories, 555 Booth Street, Ottawa, Ontario, CanadaK1A 0G1

*Corresponding authors: dogan.paktunc@canada.ca

dfortin@uottawa.ca

(C) 2015. This manuscript version is made available under the Elsevier user license

http://www.elsevier.com/open-access/userlicense/1.0/ 


\section{ABSTRACT}

Mining and metallurgical processing of gold and base metal ores can lead to the release of arsenic into the aqueous environment as a result of the weathering and leaching of As-bearing minerals during processing and following disposal. Arsenic in process solutions and mine drainage can be effectively stabilized through the precipitation of ferrihydrite.However, under anaerobic conditions imposed by burial and waste cover systems, ferrihydrite is susceptible to microbial reduction. This research, stimulated by the paucity of information and limited understanding of the microbial reduction of arsenical ferrihydrite, was conducted on synthetic adsorbed and co-precipitated arsenical 6-line ferrihydrite (Fe/As molar ratio of 10/1) using Shewanella sp. ANA-3 and Shewanella putrefaciens CN32 in a chemically defined medium containing $0.045 \mathrm{mM}$ phosphate concentration. Both bacteria were equally effective in their reducing abilities around $\mathrm{pH} 7$, resulting in initial rates of formation of dissolved As(III) of 0.10 $\mu \mathrm{M} / \mathrm{h}$ for the adsorbed, and $0.08 \mu \mathrm{M} / \mathrm{h}$ for the co-precipitated arsenical 6-line ferrihydrite samples.The solid phases in the post-reduction samples were characterizedby powder X-ray diffraction (XRD), micro-XRD, scanning electron microscopy (SEM), transmission electron microscopy (TEM), electron microprobe and X-ray absorption near edge spectroscopy (XANES) techniques. The results indicate the formation of secondary phases such as a biogenic Fe(II)As(III) compound, akaganeite, goethite, hematite and possibly magnetite during bacterial reduction experiments. Holes and bacterial imprints measuring about 1-2 $\mu \mathrm{m}$ were observed on the surfaces of the secondaryphases formed after 1200 hours of reduction. This study demonstrates the influence of $\mathrm{Fe}$ and As reducing bacteria on the release of significant concentrations of more mobile and toxic As(III) species from arsenical 6-line ferrihydrite, more readily from the adsorbed than from the co-precipitated ferrihydrite. 


\section{Introduction}

Arsenic can be released to the environment from the weathering of common arsenic bearing minerals such as arsenopyrite (FeAsS) and As-bearing pyrite $\left(\mathrm{FeS}_{2}\right)$.Mining and metallurgical processing of gold and base metal ores results in solid wastes, effluents and air emissions containing high concentrations of arsenic which form an important source of anthropogenic arsenic in the environment (Paktunc, 2009). Pyrite is one of the principal Au-bearing minerals in refractory gold ores, which is also enriched in arsenic as exemplified by a study reported by Paktunc (2008a) on the speciation of As in pyrite by X-ray absorption spectroscopy (XAS). Wastes producedas a result of pressure oxidation, roasting and smelting of gold and base metal ores form a significant source of arsenic (Paktunc, 2008a and 2008b). In the Canadian metallurgical industry, coprecipitation with ferric iron is the preferred method for the removal of arsenic from process solutions (Riveros et al. 2001). Coprecipitation with ferric iron has been designated by the USEPA as the best-demonstrated available technology for the removal of arsenic from hydrometallurgical solutions, acid mine drainage and wastewaters (Twidwelland McCloskey 2011). This processis practical and cost effective because ferric iron is readily available in metallurgical processing solutions; however, the effectiveness of this process relies heavily on the Fe/As ratio of the final precipitates and the formation of ferrihydrite instead of ferric arsenate (Paktunc et al. 2008). Indications are such that arsenic can be effectively stabilized through controlled ferrihydrite precipitation maximizing the uptake of arsenic and optimizing the kinetics of $\mathrm{FeO}_{6}$ polymerization without the presence of ferric arsenate (Paktunc 2015).

Under anaerobic conditions, dissimilatory iron reducing bacteria (DIRB) and dissimilatory arsenic reducing bacteria (DARB) use iron and arsenic as terminal electron acceptors as part of 
their metabolic processes (Lovely, 1997). Many studies have shown that the reduction of both $\mathrm{Fe}(\mathrm{III})$ and $\mathrm{As}(\mathrm{V})$ in scorodite $\left(\mathrm{FeAsO}_{4} \cdot 2 \mathrm{H}_{2} \mathrm{O}\right)$ and arsenical iron-oxyhydroxide minerals is microbially mediated (Cummings et al., 1999; Hansel et al., 2003, Papassiopi et al, 2003, Slowey et al., 2011, Revesz et al., 2015). Bacterial reduction of arsenic containing minerals results in the formation of more toxic and mobile As(III). A number of studies on the bacterial reduction of arsenical ferrihydrites have shown that dissolved $\mathrm{As}(\mathrm{III})$ is produced and that a wide range of secondary minerals can form. For instance, the reduction of intragrain 6-line ferrihydrite using Shewanella oneidensis MR-1 can produce vivianite $\left(\mathrm{Fe}^{2+}{ }_{3}\left(\mathrm{PO}_{4}\right)_{2} \cdot 8\left(\mathrm{H}_{2} \mathrm{O}\right)\right)$ (Peretyazhko et al., 2010), while the reduction of arsenical 2-line ferrihydrite with Shewanella putrefaciens CN32 (CN) generates magnetite, goethite and minor amounts of green rust (Hansel et al., 2003). The reduction of arsenical 2-line ferrihydrite in the presence of Shewanella sp. ANA-3 (ANA) also showed that dissolved As(III) was produced and that magnetite and vivianite formed as secondary minerals (Slowey et al., 2011). A study by Burnol et al. (2007), on the microbial reduction of arsenical 2-line ferrihydrite using Clostridium strain FRB1 revealed the presence of vivianite and bobierrite $\left(\mathrm{Mg}_{3}\left(\mathrm{PO}_{4}\right)_{2} \cdot 8 \mathrm{H}_{2} \mathrm{O}\right)$ in the solid phases. These microbial reduction studies of ferrihydrites that found vivianite as a secondary mineral phase were done using phosphate concentrations ranging from 1 to $2.5 \mathrm{mM}$ which are significantly higher than the concentrations normally encountered in the environment. To date, no microbial reduction studies have been performed on co-precipitatedor adsorbed arsenical ferrihydrites at low phosphate concentrations. The presence of high phosphate concentrations could lead to preferential phosphate adsorption on the ferrihydrite surfaces, blocking active sites which in turn affects the rates of reduction, as found by Amstaetter et al. (2012). This would make the results obtained at high phosphate concentrationsless applicable to mining environments. Saltikov et al (2005) 
found that phosphate and arsenate have an effect on the transcription of the arr/ars genes in Shewanella because phosphate is a structural analog of arsenate, and both can compete for uptake through the phosphate transporters, and both adsorb similarly to Fe(III) oxyhydroxides.

Accordingly, this study was carried out to investigate the influence of bacteria on the reductive dissolutionof 6-line ferrihydritewith adsorbed and co-precipitated arsenic,using Shewanella sp. ANA-3 and Shewanellaputrefaciens CN32 in a chemically defined growth medium containing $0.045 \mathrm{mM}$ phosphate, typical of mine environments. The concentrations of the dissolved aqueous species were measured, and the post-reduction solid products were characterized by X-ray diffraction, electron microscopy, electron microprobe and X-ray absorption spectroscopy techniques.

\section{Materials and Methods}

\subsection{Synthesis of adsorbed and co-precipitated arsenical 6-line ferrihydrite}

The 6-line ferrihydrite (6LFH)was synthesized using the method of Schwertmann and Cornell(2000). The adsorbed arsenical 6LFHwas prepared by re-suspending the 6LFH in about 2 $\mathrm{L}$ of a solution containing $0.16 \% \mathrm{~m} / \mathrm{v}$ sodium arsenate, $\mathrm{Na}_{2} \mathrm{HAsO}_{4} \cdot 7 \mathrm{H}_{2} \mathrm{O}$. The resulting suspension was left to settle for about a day, and the clear supernatant liquid was removed by decantation and centrifugation. The resulting precipitate wasair dried, pulverized using a mortar and pestle, and analyzed by XRD to verify its mineralogical composition. The coprecipitatedarsenical 6LFHwas prepared by adding $\left.40.5 \mathrm{~g} F\left(\mathrm{NO}_{3}\right)_{3} \cdot 9 \mathrm{H}_{2} \mathrm{O}\right)$ to a $75{ }^{\circ} \mathrm{C}$ vigorously stirred solution of $2 \mathrm{~L}$ of $0.16 \% \mathrm{~m} / \mathrm{v} \mathrm{Na}_{2} \mathrm{HAsO}_{4} \cdot 7 \mathrm{H}_{2} \mathrm{O}$ at $\mathrm{pH}$ adjusted to 3 . After stirring for 25 minutes at $75^{\circ} \mathrm{C}$, the solution was rapidly cooled to room temperature by plunging the solution container into iced water. Nitrate ions were removed from the solution by dialysis 
(Fisherbrand; Type: T2 Membranes: 6000 to 8000 Dalton MWCO; Dia. x Length: 20.4 mm x 30 m).The nitrate free suspension was evaporated to dryness, and the dark reddish-brown solid was pulverized. A sample of the product was subjected to XRD analysis to verify its mineralogical composition.

The concentrations of $\mathrm{Fe}$ and As in the samples were determined by ICP-OES.The results were in good agreement with those determined by visible spectrophotometry (i.e. ferrozine method for ironand molybdenum blue method for arsenic, as described by Revesz et al. 2015).

\subsection{Growth of the bacterial strains}

The chemically defined growth medium (CDM)contained $20 \mathrm{mM}$ sodium lactate, $4.5 \mathrm{mM}$ 1,4-piperazine-diethanesulfonic acid (PIPES) buffer, $0.01 \mathrm{mM}$ nitriloacetic acid, and trace element salts, including $0.1 \mathrm{mM} \mathrm{MgSO}{ }_{4} \cdot 7 \mathrm{H}_{2} \mathrm{O}, 2.6 \mu \mathrm{M} \mathrm{MnSO}_{4} \cdot \mathrm{H}_{2} \mathrm{O}, 0.15 \mathrm{mM} \mathrm{NaCl}, 3.2 \mu \mathrm{M}$ $\mathrm{FeSO}_{4} \cdot 7 \mathrm{H}_{2} \mathrm{O}, 3.8 \mu \mathrm{M} \mathrm{CoCl}_{2} \cdot 6 \mathrm{H}_{2} \mathrm{O}, 6.1 \mu \mathrm{M} \mathrm{CaCl}_{2} \cdot 2 \mathrm{H}_{2} \mathrm{O}, 0.93 \mu \mathrm{M} \mathrm{NaMoO} \cdot 2 \mathrm{H}_{2} \mathrm{O}, 0.36 \mu \mathrm{M}$ $\mathrm{CuSO}_{4} \cdot 5 \mathrm{H}_{2} \mathrm{O}, 0.19 \mu \mathrm{M} \mathrm{AlK}\left(\mathrm{SO}_{4}\right)_{2} \cdot 12 \mathrm{H}_{2} \mathrm{O}, 1.5 \mu \mathrm{M} \mathrm{H}_{3} \mathrm{BO}_{3}, 0.68 \mu \mathrm{M} \mathrm{Na}_{2} \mathrm{WO}_{4} \cdot 2 \mathrm{H}_{2} \mathrm{O}, 0.91 \mu \mathrm{M}$ $\mathrm{NiCl}_{2} \cdot 6 \mathrm{H}_{2} \mathrm{O}$ (Langley et al., 2009). The phosphate $\left(\mathrm{Na}_{2} \mathrm{HPO}_{4}\right)$ concentration in the chemically defined growth medium (i.e., $45 \mu \mathrm{M}$ ) was much lower than the recommended $3.9 \mathrm{mM}$ (Glasauer et. al., 2003).

For the microbial reduction experiments, a single colony of ANA or CN was transferred aseptically from the tryptic soy agar (TSA) plates to $50 \mathrm{~mL}$ of autoclaved tryptic soy broth (TSB) at $23^{\circ} \mathrm{C}$ and grown aerobically for 24 hours on a rotary shaker set at $160 \mathrm{rpm}$. From each culture, $0.5 \mathrm{~mL}$ was transferred into $50 \mathrm{~mL}$ of 50:50 TSB:CDM mixtures containing $100 \mu \mathrm{M}$ phosphate. After one day, the sub-culturing was repeated with 5:95 TSB:CDM mixtures with $100 \mu \mathrm{M}$ phosphate. The final step included the use of $100 \% \mathrm{CDM}$ with $500 \mu \mathrm{M}$ phosphate concentration 
for $36 \mathrm{~h}$ at $23^{\circ} \mathrm{C}$. This bacterial suspension was centrifuged to obtain a solid pellet which was then re-suspended in CDM with nophosphate and transferred to the microcosm bottles. The final cultures contained $0.5 \mu \mathrm{g} / \mathrm{mL}$ of total protein, based on the protocol used by Glasauer et al. (2003), which corresponded to $10^{8}$ cells $/ \mathrm{mL}$ and were adjusted to $45 \mu \mathrm{M}$ phosphate concentrations.

\subsection{Microcosms setup and sampling}

The microcosm setup was composed of $400 \mathrm{~mL}$ of sterile CDM in a $500 \mathrm{~mL}$ acidwashed, sterilized Kimax bottles. Adsorbed (called ADS) and co-precipitated (called COP) arsenical $6 \mathrm{LFH}(0.85 \mathrm{~g})$ were added to the bottles, and the $\mathrm{pH}$ was adjusted to 7 . The microcosm bottles were wrapped with aluminum foil to prevent possible photochemical reactions. The bottles were inoculated with aliquots of the bacterial cultureat time zero, inside the anaerobic chamber, using volumes of inoculum based on the protein assay absorbance measurements. Abiotic controls for the ADS and COP samples were identical to the biotic ones, but did not contain bacteria.The experiments were conducted in duplicate at room temperature inside theanaerobic chamber (atmosphere of $5 \% \mathrm{H}_{2}: 95 \% \mathrm{~N}_{2}$ ). Sampling of eachsystem was performed immediately after they were inoculated at time 0 , and subsequently at 93, 190, 383, 600, 838 and 1200 hours or 50 days. The choice of sampling times was based on a preliminary ADS and COP experiments that were run for 650 hours. The biotic systems were re-inoculated with bacteria at about 620 hours to ensure the continuation of biotic reduction, because preliminary results showed that bacteria were dying off after 650 hours. For each sub-sampling, the bottles were first shaken vigorously, and $50 \mathrm{~mL}$ aliquots were immediately withdrawn while the solid phase material remained suspended. The aliquots were placed into sterile $50 \mathrm{~mL}$ centrifuge tubes. A 
sample of about $7 \mathrm{~mL}$ was filtered through a $0.22 \mu \mathrm{m}$ cellulose acetate syringe filter into a $10 \mathrm{~mL}$ centrifuge tube for the determination of dissolved Fe. The cellulose acetate filters were recommended by Heimann and Jakobsen, (2007) for low concentrations of arsenic, because they found that filtering arsenic or phosphate-containing solutions $(1.5-47.6 \mu \mathrm{M})$ with nylon syringe filters significantly reduced the absorbance readings with the molybdenum blue method. Aliquots of about $3 \mathrm{~mL}$ were used for the determination of total Fe, culturing of bacteria and the measurement of Eh and $\mathrm{pH}$. The solid in the remaining $40 \mathrm{~mL}$ was isolated by centrifugation and decantation of the supernatant and washed 5 times before being dried in the anaerobic chamber and analyzed.

\subsection{Chemical analyses of the aqueous phase}

Redox potential measurements, using a portable Eh meter and probe (Corning redox Platinum and $\mathrm{Ag} / \mathrm{AgCl}$ combination electrode, Corning Inc.), were performed inside the anaerobic chamber on a $2 \mathrm{~mL}$ sub-sample from each microcosm bottle. The same sub-sample was then removed from the anaerobic chamber for the measurement of $\mathrm{pH}$ using a standard laboratory $\mathrm{pH}$ meter and probe (VWR).

Dissolved Fe(II), Fe(III), As(III) and As(V) concentrations were determined immediately following each sampling using the ferrozine method for iron and the molybdenum blue method for arsenic as described by Revesz et al. (2015).

The initial rates of reduction, in $\mu \mathrm{M} / \mathrm{h}$, were calculated using the slopes of the linear sections of the graphs of the dissolved Fe(II) and As(III) concentrations versus time.

\section{5. $X$-ray diffraction}


$\mathrm{X}$-ray diffraction(XRD) analyses of the pre- and post-reduction samples were performed at the Canada Centre for Mineral and Energy Technology (CANMET) with a Rigaku rotating anode X-ray powder diffractometer using a $\mathrm{Cu} \mathrm{K} \alpha$ radiation at $55 \mathrm{kV}, 180 \mathrm{~mA}$, a step-scan of $0.02^{\circ}$ and a scan rate of 1 and $2^{\circ} / \mathrm{min}$ in $2 \theta$ from $5^{\circ}$ to $70^{\circ}$. Sample preparation for the prereduction samples was done by grinding the solids with a mortar and pestle, and passing the powder through a $0.45 \mu \mathrm{m}$ sieve onto a zero background plate. Post-reduction solid samples were prepared in the anaerobic chamber by placing a few $\mathrm{mg}$ of sample finely ground with an agate mortar and pestle, in a 0.5 or $0.7 \mathrm{~mm}$ diameter quartz capillary tube, and sealing the tube with carnauba wax. The capillary tubes were mounted on a zero background plate for analysis.

Micro-XRD analyses were carried out at CANMET with a Rigaku MicroMax-007HF diffractometer, using $\mathrm{Cr} \mathrm{K} \alpha$ radiation at $35 \mathrm{kV}, 25 \mathrm{~mA}$ with a resolution of $100 \mathrm{x} 100$ pixels. In the goniometer setup, the position of the omega axis was $8^{\circ}-20^{\circ}$ with speed $2 \%$ sec, the phi axis was from $20^{\circ}-80^{\circ}$ with a speed of $2 \% \mathrm{sec}$. Collimators used were 50 and $100 \mu \mathrm{m}$ with exposure times from 5 to 15 minutes. JADE9 MDI software was used for the powder diffraction and micro-XRD data analysis.

\subsection{Scanning electron microscopy and electron microprobe analysis}

Scanning electron microscopy (SEM) analysis included placing the dried, biotic solid sample, without altering it, directly on a sticky carbon tape and imaging with a JEOL JSM6510LV SEM in low vacuum mode. Energy dispersive X-ray spectrometry (EDS), X-Max Large Area Silicon Drift Detector (SDD) size $20 \mathrm{~mm}^{2}$ with an applied voltage $20 \mathrm{kV}$, was used for elemental analysis. The EDS spectra were collected with the INCA Energy 350 spectrum analyzer software. 
The solid particles were prepared for electron microprobe analysis (EPMA) by embedding them in epoxy, mountingthem on a glass slide then polishing and carbon coating before analysis. The analysis was done with a JEOL 8230 SuperProbe electron microprobe fitted with five wavelength dispersive spectrometers and with a high count-rate silicon drift detector EDS spectrometer. The standards used were marcasite for $S(K \alpha)$, hematite for $F e(K \alpha)$, tugtupite for $\mathrm{Cl}(\mathrm{K} \alpha)$ and $\mathrm{GaAs}$ for As $(\mathrm{L} \alpha)$.

\subsection{X-ray absorption spectroscopy}

X-ray Absorption Spectroscopy measurements were carried out at the bending magnet beamline, 20-BM, of the PNC-CAT facility at the Advanced Photon Source, Argonne National Laboratory. This setup included a $\mathrm{Si}(111)$ monochromator, cryogenic apparatus, ionization chambers and a Canberra 13 element Ge detector. Sample preparation, done in an anaerobic chamber, involved mixing the pulverized sample with boron nitride to dilute the arsenic concentration to about $1 \mathrm{wt} \%$. The samples were mounted in $15 \times 4 \mathrm{~mm} \mathrm{Al} \mathrm{sample} \mathrm{holders,}$ sealed with Kapton tape on both sides, sent to the measurement site in a sealed anaerobic container, and then stored in an anaerobic chamber. The samples were positioned into the cryogenic apparatus at an angle of 45 degrees to the incident focused beam and to the Ge

fluorescence detector. The K-edge transmission and fluorescence spectra were collected simultaneously at $91 \pm 0.5^{\circ} \mathrm{K}$ using a beam size of $3500 \times 800 \mu \mathrm{m}$. Gold foil was used as a reference to monitor energy calibration. Data analysis was done with IFFEFIT and ATHENA analysis software (Ravel and Newville, 2005).

\section{Results}




\subsection{Aqueous phase analysis}

\subsubsection{Redox conditions and cell counts}

The $\mathrm{pH}$ of all biotic samples increased from 7.0 to 7.3 at 1200 hours for all systems. In the abiotic control samples the $\mathrm{pH}$ did not change. The starting or initial redox values, Eh, were $275 \pm 3 \mathrm{mV}$ for all biotic and abiotic systems (Fig. 1A and B). During the first 93 hours, the Eh values of the biotic systems decreased to $10-60 \mathrm{mV}$. Over the same time interval, Eh of the abiotic controls only decreased to $245 \mathrm{mV}$.

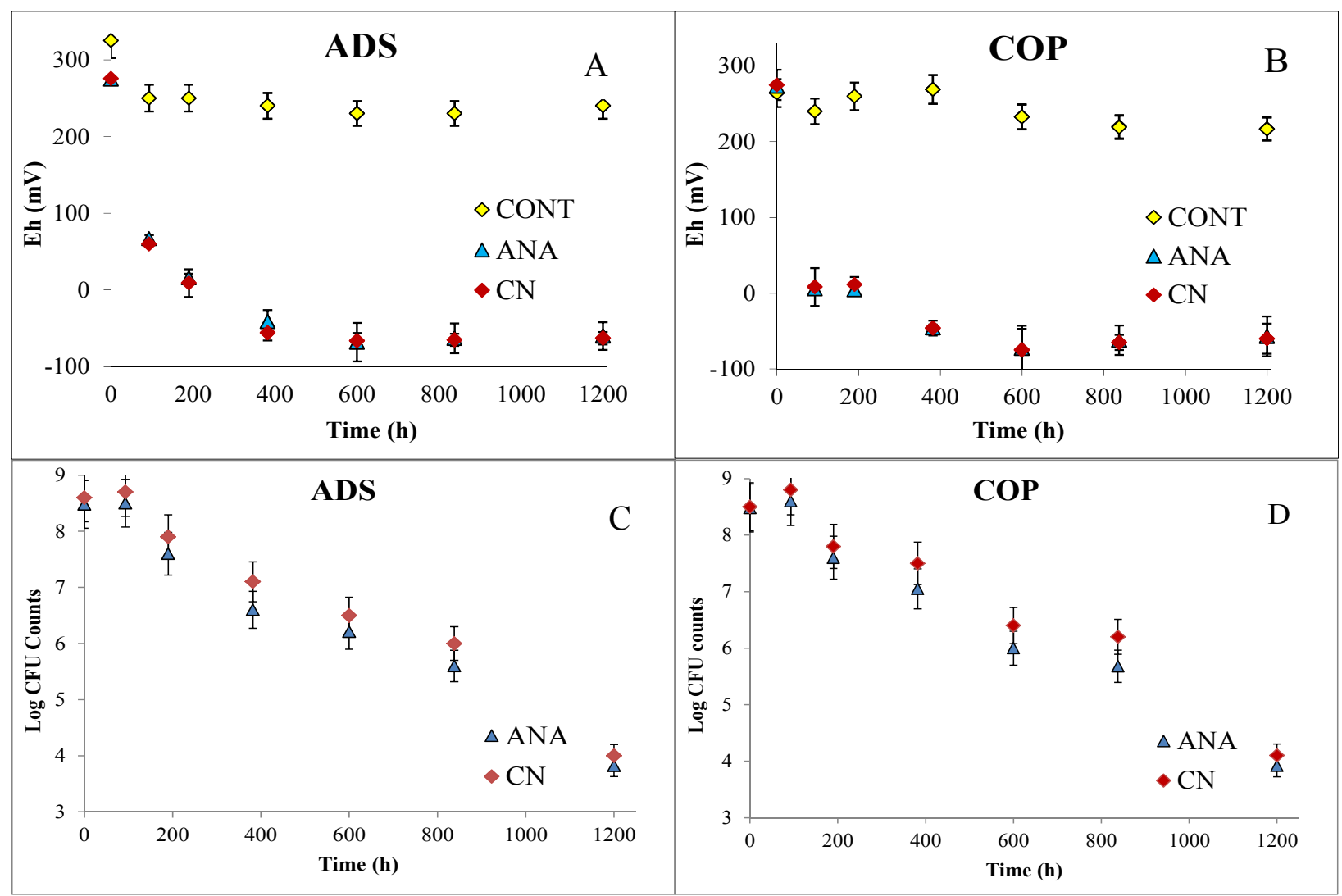

Figure 1. Changes inredox conditions $(A, B)$ and bacterial cell counts $(C, D)$ for the adsorbed(ADS) and co-precipitated (COP)arsenical 6LFH, reduced with Shewanella sp. ANA-3 (ANA) and Shewanella sp. CN32 (CN), andfor the abiotic controls (CONT). 
The initial cell counts in the biotic systems were on the order of $\sim 3 \times 10^{8} \mathrm{CFU} / \mathrm{mL}$ for both strains, and decreased over the course of the experiment reaching a final value of $1-2 \times 10^{4}$ CFU/mL for ANA and CN by 1200 hours (Fig.1 C and D). No viable bacterial cells were detected in the abiotic controls over the entire duration of the experiment.

\subsubsection{Arsenic speciation during microbial reduction}

In the abiotic control systems, the dissolved $\mathrm{As}(\mathrm{V})$ concentrations remained around $6 \mu \mathrm{M}$ for the ADS and $\sim 2 \mu \mathrm{M}$ for the COP samples at the 93 hour sampling. In both ADS and COP biotic samples, the dissolved $\mathrm{As}(\mathrm{V})$ concentrations were below $\sim 2 \mu \mathrm{M}$ at the 93 hour sampling and increased slightly to $\sim 5 \mu \mathrm{M}$ at 1200 hours (Fig. 2A).In the abiotic control systems,As(III) concentrations were below the detection limit over the duration of the experiment (Fig.2A). In the biotic ADS systems, the release of significant concentrations of dissolved As(III) started after 93 hours and increased to a plateau concentration of about $41 \mu \mathrm{M}$ by 600 hours (Fig.2A). After 620 hours, some fresh bacteria were added to keep the reduction going, which resulted in the release of additional dissolved As(III) up to about $60 \mu \mathrm{M}$ by 1200 hours. In the biotic COP systems, the release of dissolved As(III) started at around 190 hours, $\sim 100$ hours later than in the ADS samples. The addition of fresh bacteria to the biotic systems containing COP at $\sim 620$ hours also resulted in further release of dissolved As(III) to a concentration of $57 \mu \mathrm{M}$ at 1200 hours for CN and ANA (Fig.2A). 

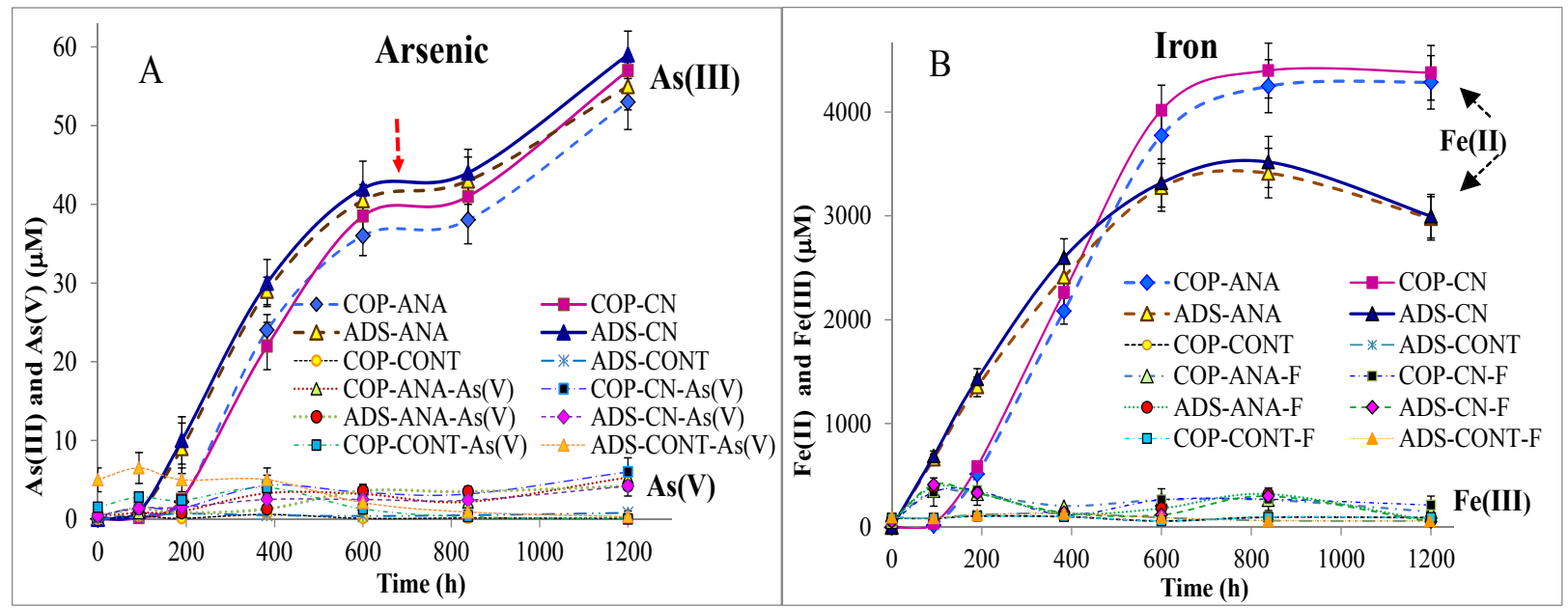

Figure 2. Dissolved $\mathrm{As}(\mathrm{III})$ and $\mathrm{As}(\mathrm{V})(\mathrm{A})$ and $\mathrm{Fe}(\mathrm{II})$ and $\mathrm{Fe}(\mathrm{III})(\mathrm{B})$ in the co-precipitated(COP) and adsorbed (ADS) arsenical 6LFH samples, reduced with Shewanella sp. ANA-3 (ANA) andShewanella sp. CN32 (CN), and in abiotic controls (CONT). The red arrow marks the time ofthe second inoculation with fresh cells.F stands for Fe(III) in the labels.

\subsubsection{Fe speciation during microbial reduction}

In the abiotic controls, the concentration of dissolved Fe(III) reached a plateau at the beginning of the experiment of $\sim 120 \mu \mathrm{M}$ for the ADS and $\sim 100 \mu \mathrm{M}$ for the COP control systems, and then remained unchanged throughout the experiment. In the biotic samples, the concentrations of dissolved Fe(III) reached values of $\sim 400 \mu \mathrm{M}$ for the $\mathrm{ADS}$ and $\sim 350 \mu \mathrm{M}$ for the COP samples at $93 \mathrm{~h}$, and then decreased to $\sim 150 \mu \mathrm{M}$ in both systems. After the addition of some fresh bacteria at $\sim 620$ hours, the Fe(III) concentration increased again to about $300 \mu \mathrm{M}$ for the ADS and $260 \mu \mathrm{M}$ for the COP samples (Fig.2B).

The release of dissolved Fe(II) in the biotic ADS samples started immediately, reaching a plateau of $\sim 3500 \mu \mathrm{M}$ at $\sim 700$ hours and then decreasing steadily to $\sim 3000 \mu \mathrm{M}$ by the end of the experiment. In the biotic COP samples, the release of dissolved Fe(II) did not start until 93 
hours, reaching a plateau of $\sim 4300 \mu \mathrm{M}$ at $\sim 700$ hours and staying around that level until the end of the experiment.

\subsubsection{The initial reduction rates of arsenic and iron}

The rates of reduction areindependentof the bacterial strain. This conclusion is supported by the values of the initial rates which were $0.100 \mu \mathrm{M} / \mathrm{h}$ for $\mathrm{CN}$ and $0.098 \mu \mathrm{M} / \mathrm{h}$ for ANA in the caseAs(III), and $13.2 \mu \mathrm{M} / \mathrm{h}$ for $\mathrm{CN}$ and $12.5 \mu \mathrm{M} / \mathrm{h}$ for ANA for Fe(II) (Fig. 2 and Table 1). Within one standard deviation for these values, there is no difference between the rates for the two bacteria (Table 1).

The releaseof $\mathrm{Fe}(\mathrm{II})$ is faster than that of $\mathrm{As}(\mathrm{III})$ for the corresponding samples which is shown by the rates of $0.100 \mu \mathrm{M} / \mathrm{h}$ for $\mathrm{As}(\mathrm{III})$, and $13.3 \mu \mathrm{M} / \mathrm{h}$ for Fe(II), using ADS and CN (Table 1), a difference in rate greater than 100 times. These differences in rates for $\mathrm{As}$ (III) and Fe(II) were obtained for both the ADS and COP samples and for both bacteria.

Statistical paired t-value analyses indicate that the rate of reduction is higher for the ADS samples than for the COP samples(Table S.5).

Table 1.Calculated initial reduction rates of $\mathrm{Fe}$ and $\mathrm{As}$ fromthe adsorbed (ADS) and coprecipitated (COP) arsenical 6LFH, reduced withShewanella sp. CN32 (CN) and Shewanella sp. ANA-3 (ANA) at $0.045 \mathrm{mM}$ phosphate concentration.

\begin{tabular}{ccccc}
\hline Species & ADS CN( $\boldsymbol{\mu M} / \mathbf{h})$ & $\begin{array}{c}\text { ADS ANA } \\
(\boldsymbol{\mu M} / \mathbf{h})\end{array}$ & $\begin{array}{c}\text { COP CN } \\
(\boldsymbol{\mu M} / \mathbf{h})\end{array}$ & $\begin{array}{c}\text { COP ANA } \\
(\boldsymbol{\mu M} / \mathbf{h})\end{array}$ \\
\hline $\mathbf{A s}(\mathbf{I I I})$ & $0.100 \pm 0.003$ & $0.098 \pm 0.004$ & $0.086 \pm 0.006$ & $0.082 \pm 0.002$ \\
$\mathbf{F e}(\mathbf{I I})$ & $7.50 \pm 0.08$ & $7.10 \pm 0.02$ & $7.80 \pm 0.70$ & $7.30 \pm 0.80$ \\
\hline
\end{tabular}




\subsection{Solid phase analysis}

\subsubsection{X-ray diffraction}

Powder XRD pattern of the post-reduction ADS and COP 6LFHreduced with Shewanella sp. ANA-3 are shown in Fig.3(A) and (B), with times of bacterial reduction in hours listed on the right. In the case of the ADS solids (Fig.3 A), the major component in the post-reduction end products remained as $6 \mathrm{LFH}$, but new secondary compounds appeared as time progressed, and their relative proportions increased with time. Analysis of the reduced ADS solids at 190 hoursshowed no evidence of formation of new secondary phases.
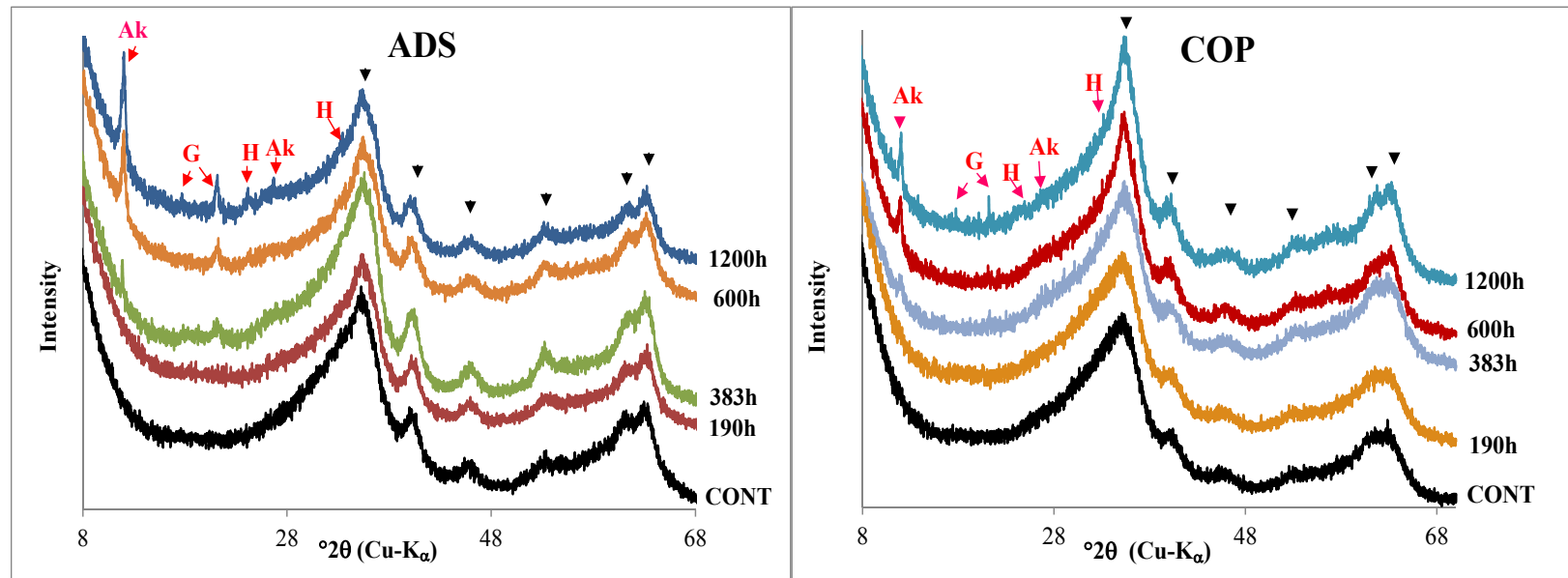

Figure 3. Powder XRD patterns of the ADS(A) and COP (B) bioticsolidsfrom 190 to 1200 hours along with control (CONT). Labels, "Ak" stands for akaganeite, "G" for goethite, "H" for hydrohematite. The black arrowheads pointto the original 6LFH peaks.

Analysis of the ADS solids after 383 hours of bacterial reduction found a small peak at $2 \theta$ of $11.9^{\circ}$, a doublet, suggesting the presence of akaganeite, and another small peak centered at $21.2^{\circ}$ suggesting the presence of goethite. As time progressed, these peaks became more prominent. After 1200 hours, another akaganeite peak appeared at $26.6^{\circ}$. Other peaks, suggesting the presence of goethite, were observed at $17.8^{\circ}$ and $36.7^{\circ}$. At 1200 hours, peaks suggesting the 
presence of hematite appeared at $24.2^{\circ}$ and $33.2^{\circ}$. In the case of the reduced COP solids (Fig. 3B), 6LFH was the major component as for the ADS solidsand the new secondary phases appeared as the bacterial reduction progressed. XRD pattern of the sample representing $190 \mathrm{~h}$ is identical to the original starting material. After 383 hours, a weak akaganeite doublet appeared at $\sim 11.5^{\circ}$ and a weak goethite peak centered at $21.2^{\circ}$.

The micro-XRD analyses of particles in the post-reduction ADS solids (Fig. 4) corroboratethe formation of akaganeite and goethite. The peak at $90.4^{\circ}$ (d spacing of $1.62 \AA$ ) couldbe an indication of the presence of magnetite. Goethite and hematite were identified in the post-reduction COP solids(Fig.4).
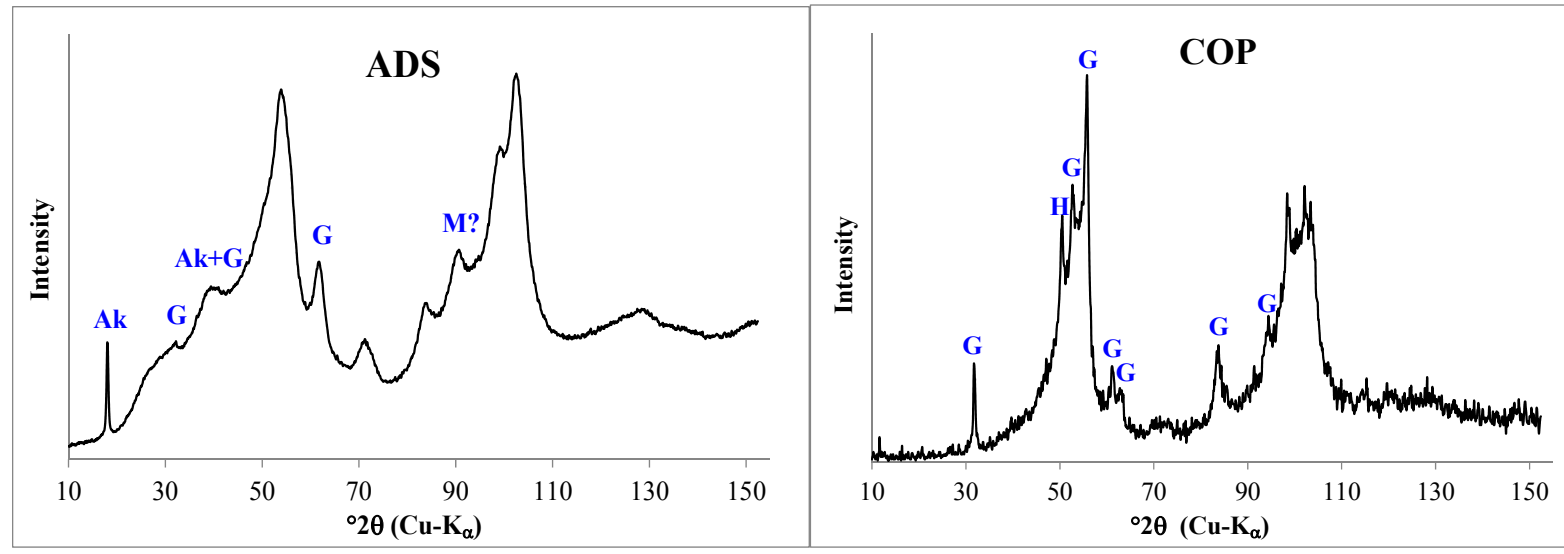

Figure 4.Micro-XRD patterns of the post-reductionsolid samples of ADS (A) and COP (B). For the ADS sample, the reflections belonged to akaganeite (Ak), goethite (G) and residual ferrihydrite (Fh). The peak marked M?at $90.4^{\circ}$ is possibly due tothe presence of magnetite. For the COP sample, the reflections were representative of goethite $(\mathrm{G})$ and hematite $(\mathrm{H})$.

\subsubsection{Scanning electron microscopy and electron microprobe}

SEM imagingof the post reduction precipitates showed various particle morphologies resembling(A) akaganeite (Fig. 5A), hydrohematite (Fig. 5B), goethite(Fig. 5C and Fig. 
S.1)andpossiblymagnetite(Fig. 5D and Fig. 6E, F). The post reduction solids identified during SEM imaging were further analyzed for elemental composition by energy dispersive spectrometry (EDS) which foundonly iron peaks, Kaand K $\beta$ around 6.4 and $7.1 \mathrm{eV}$, but noarsenic peaks, Kaand Kßaround 10.5 and $11.7 \mathrm{eV}$ were found (Fig. S.2.).

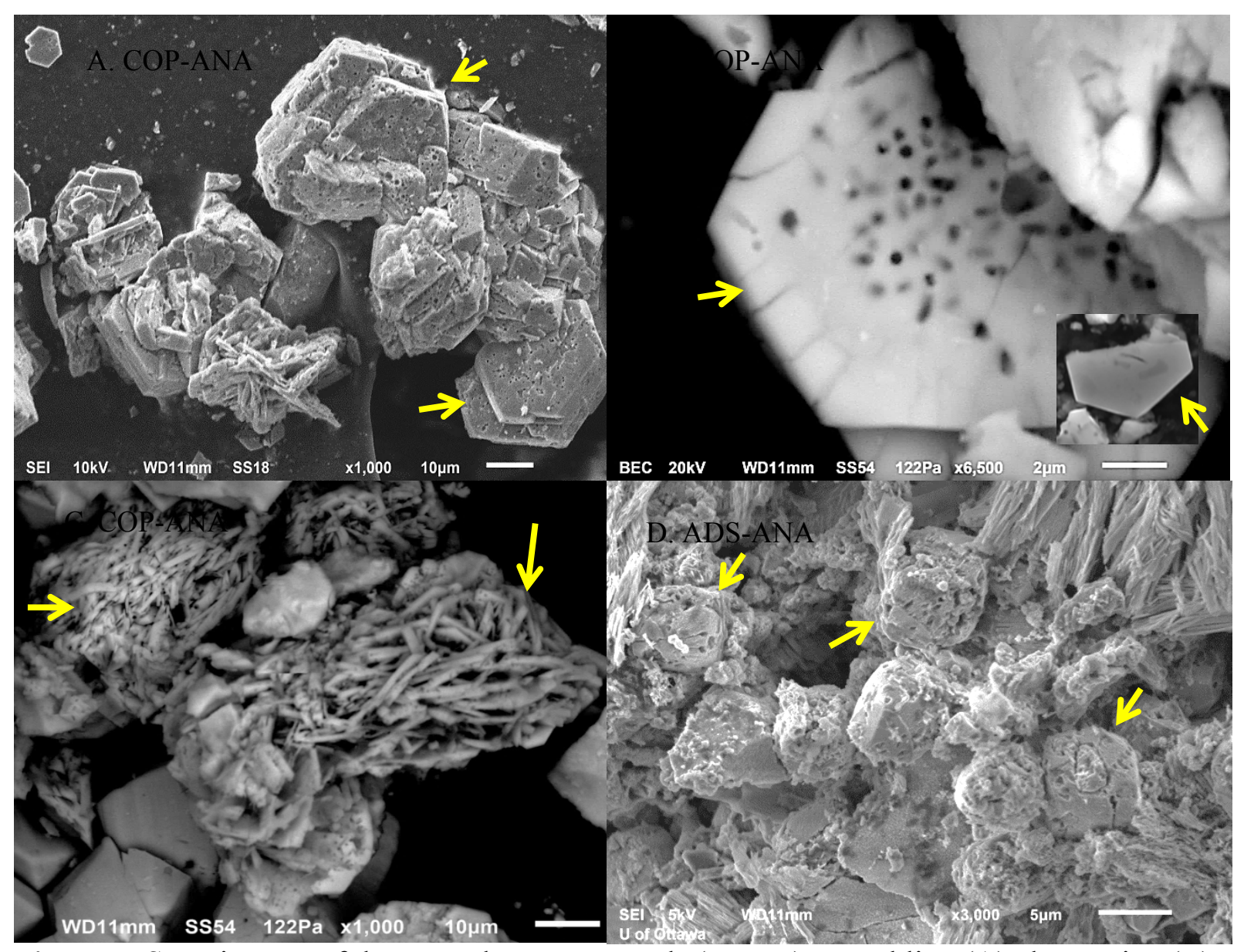

Figure 5. SEM images of the secondary compounds (arrows) resembling (A) akaganeite, (B)

hydrohematite, (C) goethite, (D) possibly magnetite in the biotic co-precipitated (COP) and adsorbed (ADS) samples after 1200 hours. Inset on (B) is at 600 hours in the COP-CN sample.

Notable features observed during SEM imaging are imprints (Fig. 6. and Fig.S.3.) ranging from about $0.2 \mu \mathrm{m}$ to about $1.5 \mu \mathrm{m}$ in diameter, etched on the surfaces of the post reduction 
solids. These imprints (Fig 6A and B) do not appear to be as deep after 600 hours as those found after 1200 hours of biotic reduction (Fig. 6C, D, E and F and Fig.S.3A,B,C and D). 


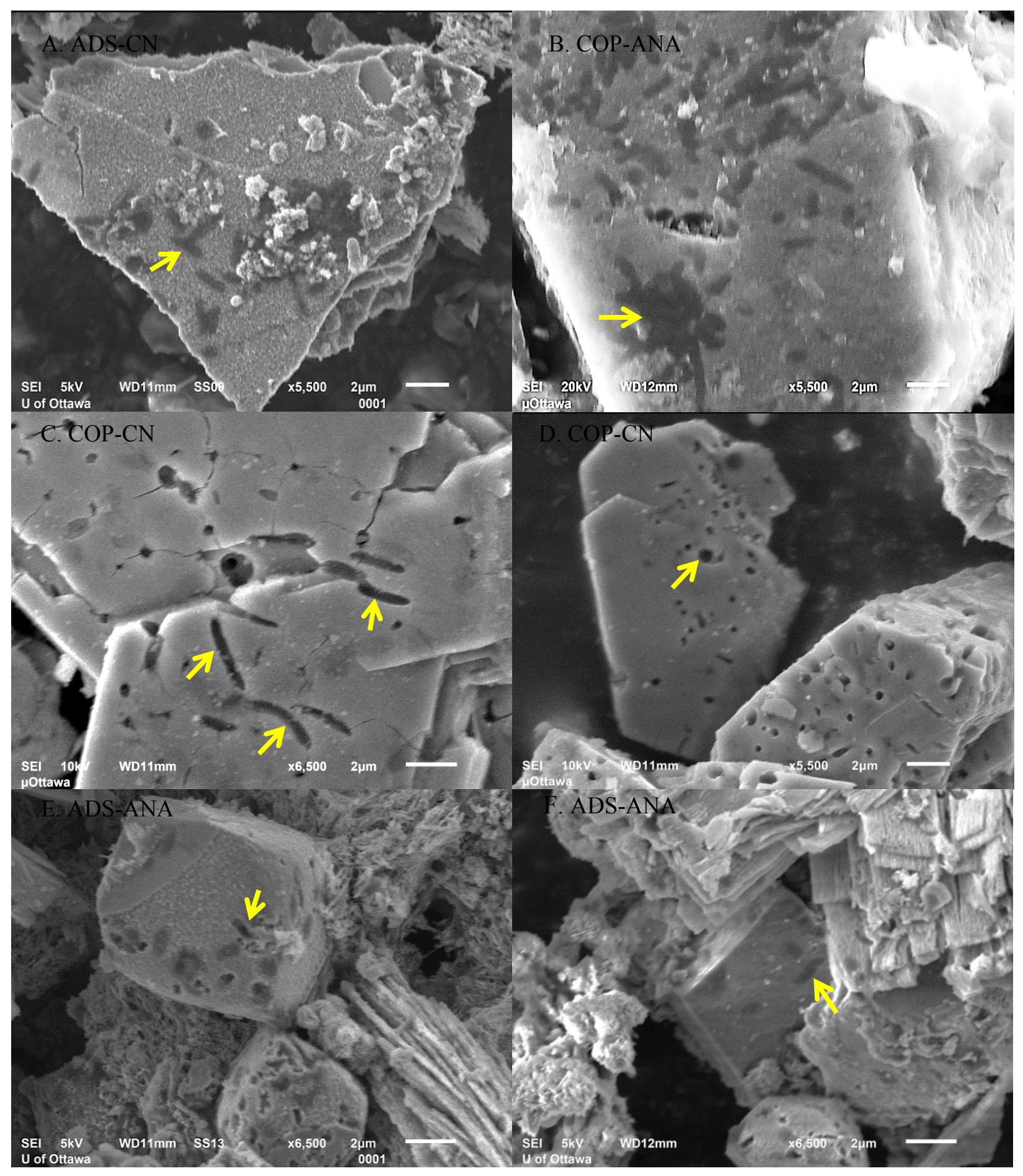

Figure 6.SEM images showing bacterial imprints (pointing arrows) (A and B) after 600 hours, (C, D, E and F) after 1200 hours of biotic reduction. 
Some of the imprints are circularly shaped, (Fig. 6D and Fig. S.3 A-D) while others are reminiscent of the size (i.e., 2 to $3 \mu \mathrm{m}$ in length and about 0.4 to $0.7 \mu \mathrm{m}$ in diameter) of the rod shapedShewanellacells (Fig. 6). The abiotic controls of the COP and ADS solid had no circular or bacterial shaped imprints on their surfaces, as shown in Fig S.3 E-F.

Electron microprobe (EPMA) analysis was used to identify the particles with ahexagonal morphology (Fig. S.4) becausegreen rust has been observed in other bioreduction experiments (Zegeye et al. 2010, Jorand et al. 2013), and both hematite and green rust have hexagonal morphologies. The EPMA analysis concluded thatthe hexagonal particles were hydrohematite.

\subsubsection{X-ray absorption spectroscopy (XAS)}

Arsenic K-edge XANES was used to determine the appearance of As(III) during the microbial reduction of ADS and COP arsenical 6LFH.As the bacterial reduction progressed, the As(III) peak at $\sim 11871 \mathrm{eV}$ became more prominent whereas the As(V) peak, at $\sim 11875 \mathrm{eV}$ gradually diminished (Fig. S.5).Linear combination fitting of the normalized As K-edge XANES spectra representing the ADS and COP samples (Fig.7A-D) using over 20 inorganic and organic arsenic reference compounds, suggested the presence of abiogenic $\mathrm{Fe}(\mathrm{II})$ As(III)compound(Babechuk et al. 2009) beside the original adsorbed arsenical 6LFH (Tables S1S4). The proportion of the original COP arsenical 6LFH decreased whereas the biogenic Fe(II)As(III) compound increased from 383 to 1200 hours.The biogenic Fe(II)-As(III) reference material contains a small fraction (10-20\%) of ferrous arsenate (Babechuck et al. 2009). 


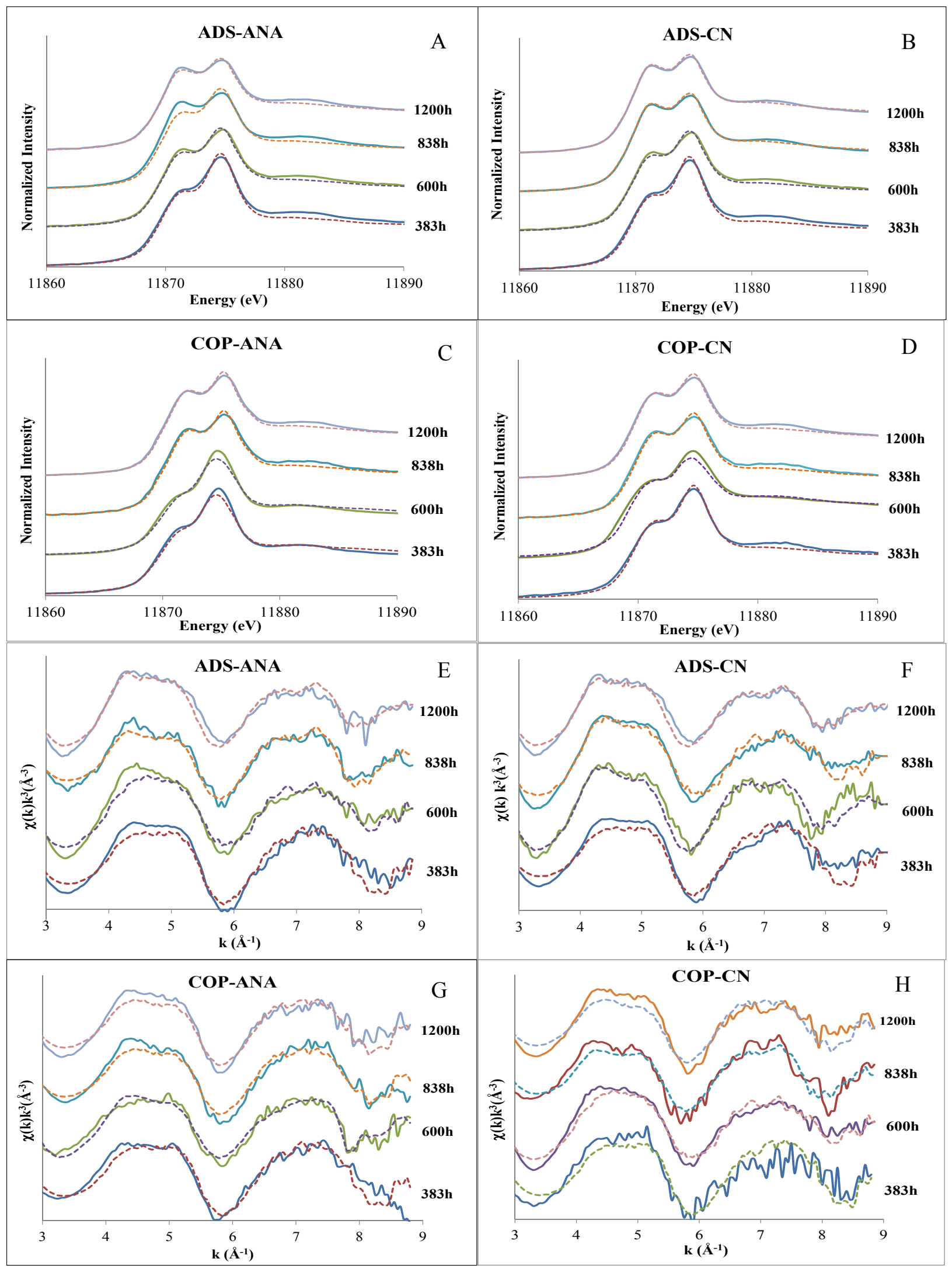


Figure 7. Arsenic K-edge XANES spectra (solid lines) and linear combination fitting (dotted lines) (A-D), andEXAFS spectra (solid lines) and linear combination fitting (dotted lines) (E-H) of ADS and COP arsenical 6-line ferrihydrite reduced withCN and ANA.

The proportions of biogenic Fe(II)-As(III) and the COP arsenical 6LFH were about equal (i.e. $50 \%$ each) at 383 hour for both strains. The final compositions of the post reduction solids were about $65 \%$ biogenic Fe(II)-As(III) and about 35\% COP arsenical 6LFH for both ANAand CN strains.

The linear combination fitting results of the $\mathrm{k}^{3}$-weighted As K-edge EXAFS spectra for the post reduction COP samples are shown in Figure7E-H and Table S4. The approximate compositions of the reduced solids were $40 \%$ biogenic Fe(II)-As(III) and $60 \%$ COP arsenical 6LFH for CN and ANA at 383 hours, and $65 \%$ biogenic Fe(II)-As(III) and $35 \%$ for CNand ANA after 1200 hours. The increase in thebiogenic Fe(II)-As(III) componentwith time in the ANA and $\mathrm{CN}$ biotic solids are shown on Figure 8.
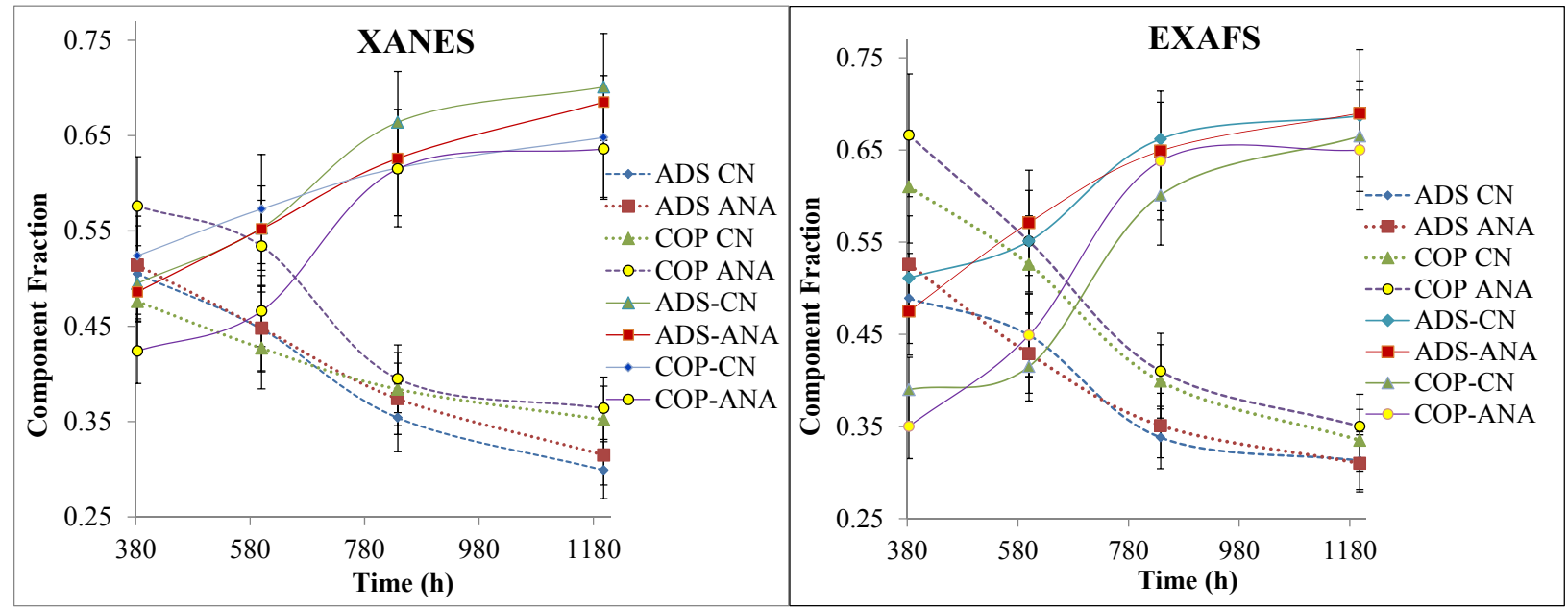
Figure 8. Fraction of secondary biogenic ferrous arsenite as a function of timefor the biotic ADS and COP residues, determined from XANES spectra (A) and from EXAFS spectra (B) and listed as Fe(II)-As(III) in Tables S1-S4.

\section{DISCUSSION}

\subsection{Aqueous phase}

\subsubsection{Arsenic speciation during microbial reduction}

No dissolved As(III) was detected in the abiotic controls, which indicates that no reduction of arsenic occurred in the absence of bacteria under the circumneutral $\mathrm{pH}$ and anaerobic conditions during the 50-day experimental period. The concentration of dissolved As(V) was $6.5 \mu \mathrm{M}$ in the ADS control and about $2 \mu \mathrm{M}$ in the COP control, which may indicate that $\mathrm{As}(\mathrm{V})$ is more readily released into solution from the ADS arsenical ferrihydrite than from the COP samples. The difference in the ease of release of $\mathrm{As}(\mathrm{V})$ mayreflect a difference in the greater accessibility of solvent to the $\mathrm{As}(\mathrm{V})$ sites in the ADS sample as opposed to adsorbed As(V) locked-in through aggregated growth of ferrihydrite particles or incorporated in the tetrahedral sites of the octahedrally-coordinated Fe structure of ferrihydrite (Paktunc et al. 2013).

The plateau concentrations of dissolved arsenic,mainly As(III) in the biotic samples, was about 10 times higher than the total dissolved arsenic concentrations in the abiotic controls. These results clearly indicate that the bacteria used in the biotic samples were effective in the release ofarsenic as reduced species from the two types of arsenical ferrihydrites.

A period of time of 93 hours, in the case of the biotic ADS samples, and 193 hours for the biotic COP samples, elapsed before significant concentrations of dissolved As(III) were detected (Fig.2). The shorter time before the detection of As(III) in the ADS sample is consistent 
with the ease of release of $\mathrm{As}(\mathrm{V})$ from $\mathrm{ADS}$ compared to COP samples. The lag phase or the adaptation phase of the bacteria which is the period of time before appreciable concentrations of the dissolved As(III) are detected, suggests that the rate of formation of As(III) may be dependent on the rate of release of $\mathrm{As}(\mathrm{V})$ from the solids. The apparent dependency of the lag phase on the form of arsenical ferrihydrite, adsorbed as opposed to co-precipitated is supported by Zobrist et al. (2000) who reported that the rate of biotic reduction of As(V) was influenced by the method in which arsenate became associated with the mineral phases.

\subsubsection{Iron speciation during microbial reduction}

Concentrations of dissolved $\mathrm{Fe}(\mathrm{III})$ in the abiotic controls remained relatively constant during the experiment, and no dissolved Fe(II) was detected, indicating that no iron reduction occurred in the absence of bacteria. Concentrations of dissolved Fe(III) in the biotic samples reached a maximum value at about 93 hours, and then gradually decreased while the concentration of the reduced iron increased. At about 620 hours when fresh bacteria were added to ensure that the microbial reduction continued, the concentration of dissolved Fe(III) increased slightly, and then decreased with time.

The plateau or the maximum measuredconcentrations of dissolved $\mathrm{Fe}(\mathrm{II})$ in the biotic ADS and COP samples were significantly higher than the concentrations of the dissolved As(III). The concentrations of dissolved Fe(II) to As(III) in the biotic ADS and COP samples were about 60:1 and about 80:1 respectively. The high dissolved Fe(II) concentrations were likely due to the high proportion of $\mathrm{Fe}(\mathrm{III})$ compared to $\mathrm{As}(\mathrm{V})$ in the original solids and to the formation of new solid phases, such as the biogenic Fe(II)-As(III) compounds. EDS analysis of some of the biogenic particles which were identified on the SEM images (Fig. S.6)found 27 atomic \% Fe and 
$17 \%$ As (Fig. S.7A) compared to the original $44 \%$ Feand 4 atomic $\%$ As (Fig. S.7B). Since the morphology of these biotic particles resemble more of a soft matter (Fig. S.6), they may have formed on the colonies of the dying bacteria on the original compounds (Fig.6 A and B) which acted as a seeding place for the formation of the biogenic Fe(II)-As(III) compound. Qi and Pichler (2014) found that adsorption of As(III) outcompeted As(V) around the potential of zero charge, about 7-8 for ferrihydrite up to $\mathrm{pH} 10$, which suggests that the arsenite may have been adsorbed onto such particles covered with organic matter (discussed in section 4.2).

\subsubsection{Arsenic and iron releases and reduction rates}

The initial rates of reduction, based on the concentrations of dissolved As(III), are higher for the ADS samples than for the corresponding COP samples, which is consistent with the greater ease of release of $\mathrm{As}(\mathrm{V})$ from the ADS samples (Table 1). The initial rates of reduction based on the concentration of the dissolved Fe(II) are significantly greater than the rates based on As(III).No significant difference in rates, based on Fe(II), were found between ADS and COP samples, nor did the two bacteria exhibit any significant difference in their influence on rates.Considering that the concentrations of dissolved $\mathrm{Fe}(\mathrm{III})$ are low, the rates of $7-8 \mu \mathrm{M} / \mathrm{h}$ based on $\mathrm{Fe}(\mathrm{II})$ would be representative of the total Fe releases from the reductive dissolution of ferrihydrite.Both Shewanella sp. ANA-3 and ShewanellaputrefaciensCN32 were effective in the reductive dissolution of ferrihydrite with adsorbed and co-precipitated arsenic.

Initial reduction rates of $\mathrm{Fe}(\mathrm{III})$ in arsenic-free 2-line ferrihydrite reduced with ShewanellaputrefaciensCNwere reported as $26 \mu \mathrm{M} / \mathrm{h}$ by Roden et al., (2003) and $55 \mu \mathrm{M} / \mathrm{h}$, under advective flow conditions (Hansel et al., 2004). Our initial reduction rates of $\mathrm{Fe}(\mathrm{III})$ in arsenical 6-line ferrihydrite are $7.5 \mu \mathrm{M} / \mathrm{h}$ for the ADS samples with $\mathrm{CN}$ and $7.1 \mu \mathrm{M} / \mathrm{h}$ with ANA-3, and 
$7.9 \mu \mathrm{M} / \mathrm{h}$ with $\mathrm{CN}$ and $7.1 \mu \mathrm{M} / \mathrm{h}$ with ANA for the COP samples. The lower Fe(III) reduction rates measured in our experiments for the arsenical ADS and COP samples, compared to the arsenic-free ferrihydrite reduction rates reported in the literature, may be explained by the higher crystallinity of our ferrihydrite and the blockage of the reactive Fe(III) sites by arsenic (Waychunas et al. 1993; Erbs et al. 2010).

\subsection{Solid phase analysis}

Dissolved Fe(II) concentrations in the biotic ADS samples werelower than those in the COP samples (Fig. 2B). The proportion of biogenic Fe(II)-As(III) increased with time at a greater rate in the ADS samples than in the COP post-reduction solid samples which may account for the lower dissolved Fe(II) concentration in the ADS samples.A comparison of the powder XRD results for the ADS and COP samples (Fig. 3) shows that the intensity of peaks characteristic of the secondary mineral phases are higher for ADS than for COP samples, indicating the presence of more reduced solid phases and formation of secondary akaganeite, goethite, hematite and possibly magnetite. The XRD patterns shown in Figure3 indicate that the formation of the secondary compounds was a gradual process withthe akaganeite and goethite peaks appearingaround 400 hours for the ADS and around 600 hours for the COP samples, while the magnetite and hematiteappeared later in time. Studies by Kukkadapu et al. (2004), Pedersen et al. (2005) and Rosso et al. (2010) revealed that dissolved Fe(II) catalyzes the formation of new secondary minerals. Hansel et al. (2003) found that the addition of as little as $0.04 \mathrm{mM} \mathrm{Fe}(\mathrm{II})$ led to the transformation of significant proportion of ferrihydrite to more stable secondary iron hydroxide phases in a period of just over a week. 
SEM imaging (Fig.6) revealed the presence of secondary minerals identified by XRD and micro-XRD (i.e., akaganeite, hydrohematite and goethite) (Fig.3and 4).The presence of magnetite is suspected but not confirmed. Formation of magnetite during bacterial reduction of ferrihydrite with Shewanella putrefaciens CN32 was reported by Hansel et al. (2003)and Pallud et al. (2010), and with Shewanella sp. ANA-3 by Slowey et al. (2011). A study of an abiotic system by Baumgartner et al. (2013) found magnetite after the addition of Fe(II) to 6LFH in solution. In our study, identification of magnetite is based on the isometric morphology of the precipitates resembling magnetite (Figs.6D, E, F and 7E, F).

Electron microprobe analyses of the secondary phase with hexagonal outlines suggest that it is hydrohematite $\left(\alpha-\mathrm{Fe}_{2} \mathrm{O}_{3} \cdot \mathrm{nH}_{2} \mathrm{O}\right)$. Microbial reduction studies have shown that a variety of factors may influence the relative tendencies to form hematite, green rust or other secondary minerals. Zegeye et al. (2010) showed that the formation of green rust as opposed to magnetite depended on bacterial cell density, and Jorand et al. (2013) found that, in addition to phosphate concentrations, properties of polymers that can include bacterial exopolymers are critical parameters that control the formation of secondary phases in the presence of bacteria.

Ferrihydritepeaks of the biotic COP samples became progressively sharper with time, suggesting the improvement in crystallinity or particle growth with time (Fig. 3). The COP particles were smaller due to the presence of arsenate during co-precipitation with ferrihydriteprobably because the arsenic in solution may have blocked the reactive growth sites.

The akaganeite peaks appeared at around 400 hours on the XRD (Fig.3) of the biotic ADS and COP samples, and the peaks for the ADS sample weremore intense than those of the COP sample. In our ADS and COP experiments, the amount of akaganeite increased as the experiment progressed, and reached the highest value after 1200 hours.As in the case of 
akaganeite, goethiteappeared at around 400 hours. Two different types of morphology,observed under SEM can correspond to goethite, which arelonger,striped structures(Fig.6C bottom right) and shorter, crystallized needles on the surface of the COP sample (Fig. S.1B).Hansel et al. (2005) found that the reaction of aqueous Fe(II) with ferrihydrite resulted in the precipitation of goethite $(\alpha-\mathrm{FeOOH})$, lepidocrocite $(\gamma-\mathrm{FeOOH})$, and magnetite $\left(\mathrm{Fe}_{3} \mathrm{O}_{4}\right)$, depending on the $\mathrm{Fe}(\mathrm{II})$ concentration. Yang et al. (2010) found that aqueous Fe(II) adsorption on 6LFH formed different secondary minerals depending on the aqueous Fe(II) concentration, goethite being formed at lower $\mathrm{Fe}(\mathrm{II})$ concentrations and magnetite being formed at higher Fe(II) concentrations.

XANES spectra indicated the formation of the new biogenic Fe(II)-As(III) compound at the expense of the original 6LFH(Tables S1-S4, Fig. 7). The association of iron and arsenic with microbial exopolymeric substances (EPS) was reported by Babechuk et al. (2009), Peretyazhko et al. (2010), Hohmann et al. (2011) and Huang et al. (2011). One of the main reasonsfor the As(III) binding to exopolymeric substances is that the proteins contain amino acids with sulfhydryl (-SH) functional groups which have a high affinity for As(III) (Shen et al. 2013). The high affinity of $\mathrm{As}(\mathrm{III})$ for - $\mathrm{SH}$ groups in proteins is probably one of the main reasons why As(III) is much more toxic than $\mathrm{As}(\mathrm{V})$. Other studies have suggested that As(III) produced during bacterial reduction could be incorporated in the structure of secondary mineral phases (Kocar et al., 2006; Tufano and Fendorf, 2008). Hansel et al. (2003) observed precipitation of $\mathrm{Fe}(\mathrm{II})$ on the extracellular surface of Shewanella putrefaciens CN32 after 9 days of reduction. The surfaces of the dead bacterial extracellular matrix might function as potential binding sites for the dissolved $\mathrm{Fe}(\mathrm{II})$ and $\mathrm{As}(\mathrm{III})$, and lead to the formation of biogenic $\mathrm{Fe}(\mathrm{II})-\mathrm{As}(\mathrm{III})$ precipitate (Figs. S.6 and S.7).Exopolymeric substances have other surface functional groups, such as carboxyl and phosphoryl groups, which are deprotonated at $\mathrm{pH} 7$ and can bind $\mathrm{Fe}(\mathrm{II})$ 
from the close proximity of the ferrihydrite surface. Therefore the structure of the bacterial exopolymeric substances may have played a role in the formation of the biogenic Fe(II)-As(III) compound.

The role of phosphate concentrations on the bacterial reduction of arsenical ferrihydrites can be determined in part by considering the nature of the post reduction solids. Vivianite $\left(\mathrm{Fe}^{2+}{ }_{3}\left(\mathrm{PO}_{4}\right)_{2} \cdot 8\left(\mathrm{H}_{2} \mathrm{O}\right)\right)$ was the dominant secondary product found at phosphate concentrations higher than those present in the natural environment. In the present study, carried at $0.045 \mathrm{mM}$ phosphate, typical of the natural environments, no vivianite was detected, but other secondary compounds including akaganeite, goethite, hydrohematite and possibly magnetite were found. A comparison of the results at different phosphate concentrations addressed in arecent paper by Revesz et al. (2015) on the bacterial reduction of scorodite suggests that great care must be exercised in interpreting the results obtained at phosphate concentrations that are not representative of the mine environments.

\subsection{Bacterial imprints}

The bacterial imprints present on the post-reduction particles(Fig.6A and B), are similar to those observed by Brookshaw et al. (2014) on biotite reduced by Shewanella. The etched rod shaped and circular bacterial imprints observed on hematite particles (Fig.5B, 6C and D)resemble those found in other studies (Mustin et al. 1992; Edwards and Rutenberg, 2001; Rojas-Chapana and Tribusch,2004; Ndlovu and Monhemius, 2005 and Baranska and Sadowski, 2013).After 600 hours of reduction, we found very few imprints on the surfaces of some of the newly formed secondary precipitates (Fig.5B inset, 5D and 6D inset). However, after reinoculation(around 620 hours), it appears that the freshly added bacteria started to colonize the 
surfaces of the newly formed, mainly Fe(III) secondary precipitates which had no imprints (Fig. S.1A). ANA and CN strains can grow better when using $\mathrm{Fe}(\mathrm{III})$ as opposed to $\mathrm{As}(\mathrm{V})$ as an electron acceptor. This is supported by the fact that the standard reduction potential $\left(\mathrm{E}^{\circ}\right)$ of $\mathrm{Fe}(\mathrm{III}) / \mathrm{Fe}(\mathrm{II})$ is $0.77 \mathrm{mV}$ whereas that for $\mathrm{As}(\mathrm{V}) / \mathrm{As}(\mathrm{III})$ is $0.58 \mathrm{mV}$ (CRC Handbook, 19721973).We found more etched imprints towards the middle of the hydrohematite surface (Fig. 5B and Fig. 6C) suggesting that the interior of the basal plane was older than the outer regions compared to crystalline faces of other secondary minerals, like magnetite on Figures6E and F. This observation supports the findings of Neal et al. (2003) who found significantly more Shewanella cells on the hematite basal face compared to the magnetite (100) and (111) faces, and their modeling predicted electron transfer rates that are about two orders of magnitude higher for

the hematite basal face than for the two faces of magnetite. Yanina and Rosso (2008) and Chatman et al. (2013) found surface electric potential gradients across structurally distinct crystal faces of hematite exposed to solution, which makes it more favourable for the bacteria to associate with crystal faces where they can get the highest electron supply for maintenance.

\section{Overall summary and conclusion}

The dissimilatory iron and arsenic reducing (DIRB/DARB) bacteria, Shewanella sp. ANA-3 and Shewanella putrefaciens CN32, used in this experiment at circumneutral pH and under anaerobic conditions caused the reductive dissolution of adsorbed and co-precipitated arsenical 6LFH, resulting in the release into solution of Fe(II) and of As(III), a more toxic form of arsenic than $\mathrm{As}(\mathrm{V})$. The new secondary minerals found in the post-reduction products of the ADS and COP 6LFH solid samples were a biogenic Fe(II)-As(III) compound, akaganeite, goethite, hydrohematite and possibly magnetite for both bacteria. The concentrations of the 
products of bacterial reduction of the adsorbed and co-precipitated6LFH were about $3.5 \mathrm{mM}$ Fe(II) and about $0.057 \mathrm{mM} \mathrm{As(III)} \mathrm{for} \mathrm{the} \mathrm{ADS,} \mathrm{and} \mathrm{about} 4.3 \mathrm{mM} \mathrm{Fe}(\mathrm{II})$ and about $0.055 \mathrm{mM}$ As(III) for the co-precipitated samples.

These findings indicate that under anaerobic conditions and circumneutral $\mathrm{pH}$ arsenical 6LFH are unstable with respect to microbial reduction, and this finding should be taken into account when using ferrihydrite as a means to sequester arsenic.

\section{Acknowledgements}

This project was partially funded by NSERC Discovery grants to D.F. and D.P and by CANMET. E.P thanks Derek Smith at CANMET for XRD and Glenn Poirier for the electron microprobe analysis and Robert Gordon for the XAS measurements which were performed at the Pacific Northwest Consortium-Collaborative Access Team's (PNC/XOR) beamline at the Advanced Photon Source (APS) at the Argonne facility under the user agreement to D.P. Argonne National Laboratory is supported by the US Department of Energy under Contracts W31-109-Eng-38 (APS) and DE-FG03-97ER45628 (PNC-CAT).

\section{References:}

Amstaetter, K., Borch, T., Kappler, A., 2012. Influence of humic acid imposed changes of ferrihydrite aggregation on microbial Fe(III) reduction.Geochim. Cosmochim. Acta 85, $326-341$. 
Babechuk, M. G., Weisener, C. G., Fryer, Brian J., Paktunc, D., Maunders, C., 2009. Microbial reduction of ferrous arsenate: Biogeochemical implications for arsenic mobilization. Appl. Geochem. 24, 2332-2341.

Baranska, J.A., Sadowski, Z., 2013. Bioleaching of uranium minerals and biosynthesis of $\mathrm{UO}_{2}$ nanoparticles. Physicochem. Probl. Miner. Process, 49, 71-79.

Baumgartner, J., Dey, A., Bomans, P.H.H., Le Coadou, C., Fratzl, P., Sommerdijk, N. A. J. M., Faivre, D., 2013. Nucleation and growth of magnetite from solution. Nat. Matter. 12, 312-314.

Brookshaw, D.R., Lloyd, J.R., Vaughan, D.J., Pattrick, R.A.D., 2014.Bioreduction of biotite and chlorite by a Shewanella species.Am. Mineral.99, 1746-1754.

Burnol, A., Garrido, F., Baranger, P., Joulian, C., Dictor, M-C., Bodénan, F., Morin, G., Charlet, L., 2008. Decoupling of arsenic and iron release from ferrihydrite suspension under reducing conditions: a biogeochemical model. Geochem. T. 8, 12-30.

Chatman, S., Zarzycki, P., Rosso, K.M., 2013. Surface potentials of (001), (012), (113) hematite $\left(\alpha-\mathrm{Fe}_{2} \mathrm{O}_{3}\right)$ crystal faces in aqueous solution. Phys. Chem. Chem. Phys. 15, $13911-13921$.

CRC Handbook of Chemistry and Physics, $53^{\mathrm{RD}}$ Edition, 1972-1973. Page: D111

Cummings, D.E., Caccavo, F., Fendorf, S., Rosenzweig, R.F., 1999. Arsenic mobilization by the dissimilatory Fe(III)-reducing bacterium Shewanella algaBrY. Environ. Sci. Technol.33, $723-729$.

Edwards, K.J., Rutenberg, A.D., 2001. Microbial response to surface microtopography: the role of metabolism in localized mineral dissolution. Chem. Geol. 180, 19-32. 
Erbs, J.J, Berquo, T. S., Reinsch, B. C., Lowry G. V., Banerjee, S. K., Penn, R.L., 2010. Reductive dissolution of six-line ferrihydrite. Geochim. Cosmochim. Acta 74, 33823395.

Glasauer, S., Weidler, P.G., Langley, S., Beveridge, T.J., 2003. Controls on Fe reduction and mineral formation by a subsurface bacterium. Geochim. Cosmochim. Acta 67, 12771288.

Hansel, C.M., Benner, S.G., Neiss, J., Dohnalkova, A., Kukkadapu, R.K., Fendorf, S., 2003. Secondary mineralization pathways induced by dissimilatory iron reduction of ferrihydrite under advective flow. Geochim. Cosmochim. Acta 67, 2977-2992.

Hansel, C.M., Benner, S.G., Nico, P., Fendorf, S., 2004. Structural constraints of ferric (hydr)oxides on dissimilatory iron reduction and the fate of $\mathrm{Fe}$ (II).Geochim. Cosmochim. Acta 68, 3217-3229.

Hansel, C.M., Benner, S.G., Fendorf, S., 2005. Competing Fe(II)-induced mineralization pathways of ferrihydrite. Environ. Sci.Technol. 39, 7147-7153.

Heimann,A.C., Jakobsen, R., 2007. Filtration through nylon membranes negatively affects analysis of arsenic and phosphate by the molybdenum blue method. Talanta $72,839-841$.

Hohmann, C., Morin, G., Ona-Nguema, G., Guigner,J-M., Brown, G.E.Jr., Kappler, A., 2011. Molecular-level modes of As binding to Fe(III) (oxyhydr)oxides precipitated by the anaerobic nitrate-reducing Fe(II)-oxidizing Acidovorax sp. strain BoFeN1. Geochim. Cosmochim. Acta 75, 4699-4712.

Huang, J-H., Voegelin, A., Pombo, S.A., Lazzaro, A., Zeyer, J., Kretzschmar, R., 2011. Influence of arsenate adsorption to ferrihydrite, goethite, and boehmite on the kinetics of 
arsenate reduction by Shewanella putrefaciens strain CN-32. Environ. Sci. Technol. 45, $7701-7709$.

Jorand, F.P.A. Sergent, A.S., Remy, P.PH., Bihannic, I., Ghanbaja, J. Lartiges, B., Hanna, K., Zegeye, A., 2013. Contribution of anionic vs. neutral polymers to theformation of green rust from $\gamma$-FeOOH bioreduction.Geomicrobiol. J. 30, 600-615

Kocar, B.D., Herbel, M.J., Tufano K.J. and Fendorf,S., 2006. Contrasting effects of dissimilatory iron(III) and arsenic(V) reduction on arsenic retention and transport. Environ. Sci.Technol. 40, 6715-6721.

Kukkadapu, R.K., Zachara. J.M., Fredrickson. J.K., Kennedy, D.W., 2004. Biotransformation of two-line silicaferrihydrite by a dissimilatory Fe(III)-reducing bacterium: Formation of carbonate green rust in the presence of phosphate. Geochim. Cosmochim. Acta 68, 27992814.

Langley, S., Gault, A.G., Ibrahim, A., Renaud, R., Fortin, D., Clark, I.D. and Ferris, F.G., 2009. A comparison of the rates of Fe(III) reduction in synthetic and bacteriogenic iron oxides by Shewanella putrefaciens CN32. Geomicrobiol. J. 26, 57-70.

Lovley, D.R., 1997. Microbial Fe(III) reduction in subsurface environments. FEMSMicrobiol. Rev. 20,305-315.

Mustin, C., Bethelin, J., Marion, P. and De Donato, P. 1992. Corrosionand electrochemical oxidation of a pyrite by Thiobacillus ferrooxidans.Appl. Environ. Microbiol. 58, 11751182.

Ndlovua, S., Monhemius, A.J., 2005. The influence of crystal orientation on the bacterial dissolution of pyrite. Hydrometallurgy 78, 187-197. 
Neal, A.L., Rosso, K.M., Geesey, G.G., Gorby, Y.A. Little, B.J., 2003. Surface structure effects on direct reduction of iron oxides by Shewanella onedensis, Geochim. Cosmochim. Acta 67, 4489-4503.

Pallud,C., Masue-Slowey,Y., Fendorf,S., 2010. Aggregate scale spatial heterogeneity in reductive transformation of ferrihydrite resulting from coupled biogeochemical and physicalprocesses. Geochim. Cosmochim. Acta 74, 2811-2825.

Paktunc, D., 2008a. Speciation of Arsenic in Pyrite by Micro-X-Ray AbsorptionFine-Structure Spectroscopy (XAFS) Ninth International Congress for Applied Mineralogy Brisbane, QLD, Australia, 8 - 10 September.

Paktunc, D., 2008b. Speciation of arsenic in an anaerobic treatment system at $\mathrm{aPb}-\mathrm{Zn}$ smelter site, gold roaster products, $\mathrm{Cu}$ smelter stack dust and impacted soil. Ninth International Congress for Applied Mineralogy Brisbane, QLD, Australia, 8 - 10 September.

Paktunc, D., 2009.Arsenic speciation in wastes resulting from pressure oxidation, roasting andsmelting. Proceedings of the 24th International Applied Geochemistry Symposium (IAGS); June 1-4, 2009, Fredericton, Canada, Eds. D.R. Lentz, K.G. Thorne, K-L. Beal, vol.II, 881-884.

Paktunc, D., 2015. Phase transformations in the $\mathrm{Fe}-\mathrm{AsO}_{4}-\mathrm{SO}_{4}$ system and structure of amorphous ferric arsenate: implications for arsenic stabilization in mine drainage and industrial effluents. Canadian Mineralogist (in press).

Paktunc, D., Dutrizac, J., Gertsman, V., 2008. Synthesis and phase transformations involving scorodite, ferric arsenate and arsenical ferrihydrite: Implications for arsenic mobility. Geochim. Cosmochim. Acta. 72, 2649-2672. 
Paktunc, D., Manceau, A., Dutrizac, J., 2013. Incorporation of Ge in ferrihydrite: Implications for the structure of ferrihydrite. Amer. Mineral. 98, 848-858.

Papassiopi, N., Vaxevanidou, K., Paspaliaris, I., 2003. Investigating the use of iron reducing bacteria for the removal of arsenic from contaminated soils. Water, Air \& Soil Poll. Focus, 3.81-90.

Pedersen, H., Postma, D., Jacobsen, R., 2006. Release of arsenic associated with the reduction and transformation of iron oxides. Geochim. Cosmochim. Acta 70, 4116-4129.

Peretyazhko, T.S., Zachara, J.M., Kennedy, D.W., Fredrickson, J.K., Arey, B.W.,McKinley, J.P., Wang, C.M., Dohnalkova, A.C., Xia, Y., 2010. Ferrous phosphate surface precipitates resulting from the reduction of intragrain 6-line ferrihydrite by Shewanellaoneidensis MR 1. Geochim. Cosmochim. Acta 74, 3751-3767.

Qi, P., Pichler, T., 2014. Closer look at As(III) and As(V) adsorption onto ferrihydrite under competitive conditions. Langmuir 30, 11110-11116.

Ravel, B., Newville, M.2005. ATHENA, ARTEMIS, HEPHAESTUS:data analysis for X-ray absorption spectroscopy using IFEFFIT. J.Synchrotron. Radiat. 12, 537-541.

Revesz, E., Fortin, D., Paktunc, D., 2015.Redox stability of scorodite in the presence of Schewanellasp. CN32 and Schewanellasp. ANA-3.Applied Geochemistry (in press).

Riveros, P.A., Dutrizac, J.E., Spencer, P., 2001. Arsenic disposal practices in the metallurgical industry. Can. Metall. Q. 40, 395-420.

Roden, E.E., 2003. Fe(III) oxide reactivity toward biological versus chemical reduction. Environ. Sci. Technol. 37, 1319-1324.

Rojas-Chapana, J.A., Tributsch, H., 2004. Interfacial activity and leaching patterns ofLeptospirillum ferrooxidans on pyrite. FEMS Microbiol. Ecol. 47, 19-29. 
Saltikov, C.W., Wildman, R.A. Jr., Newman,D.K., 2005. Expression dynamics of arsenic respiration and detoxification in Shewanella sp. Strain ANA-3. J. Bacteriol. 187,73907396.

Schwertmann, U., Cornell, R.M., 2000. Iron oxides in the laboratory: Preparation and characterization, Wiley-VCH, p: 104-105.

Shen, S., Li, X-F., Cullen, W.R., Weinfeld, M., Le, X. C., 2013. Arsenic binding to proteins. Chem. Rev. 113, 7769-7792.

Slowey, Y.M., Kocar, B.D., Jofre, S.A.B., Mayer. K.M., Fendorf, S., 2011. Transport implications resulting from internal redistribution of arsenic and iron within constructed soil aggregates. Environ. Sci. Technol. 45, 582-588.

Tufano, K. J., Fendorf, S. 2008. Confounding impacts of iron reductionon arsenic retention. Environ. Sci. Technol. 42, 4777-4783.

Twidwell, L.G., McCloskey, J.W. 2011. Removing arsenic from aqueous solution and long-term product storage. J. Metallurgy 63, $94-100$.

Waychunas, G.A., Rea, B.A., Fuller, C.C., Davis, J.A., 1993. Surface chemistry of ferrihydrite: Part 1. EXAFS studies of the geometry of co-precipitated and adsorbed arsenate. Geochim. Cosmochim. Acta 57, 2251-2269.

Yang, L., Steefel, C.I., Marcus, M.A., Bargar, J.R., 2010. Kinetics of Fe(II)-catalyzed transformation of 6-line ferrihydrite under anaerobic flow conditions. Environ. Sci. Technol. 44, 5469-5475.

Yanina, S.V., Rosso, K.M., 2008. Linked reactivity at mineral-water interfaces through bulk crystal conduction. Science 320, 218-222.

Zegeye A, Mustin C, Jorand F. 2010. Bacterial and iron oxide aggregates mediate secondary 
iron mineral formation: green-rust vs magnetite. Geobiology 8, 209-222.

Zobrist. J., Dowdle, P.R., Davis, J.A, Oremland, R.S., 2000. Mobilization of arsenite by dissimilatory reduction of adsorbed arsenate. Environ. Sci.Technol. 34, 4747-4753. 